\title{
COMMENTS
}

\section{THE RIGHT OF PRIVACY: NORMATIVE-DESCRIPTIVE CON- FUSION IN THE DEFENSE OF NEWSWORTHINESS}

In an article published in 1890,1 Messrs. Warren and Brandeis, personally irritated by the gossip-mongering of the Boston newspapers, called attention to the excesses of the press in publicizing individuals' affairs, names and likenesses, and urged that a new cause of action be established to remedy the evil. Wide recognition of the tort of "invasion of privacy" has followed. In conformity with the suggestions of that article, thirty-three jurisdictions have recognized various forms of the right to privacy, either by judicial decision or statute. 2 In only four has it been rejected by the courts and not acknowledged by the legislature. ${ }^{3}$ The question has been left open in six. ${ }^{4}$ No cases have been

1 Warren \& Brandeis, The Right to Privacy, 4 HaRv. L. Rev. 193 (1890).

${ }_{2}^{2}$ Some decisions are set forth below. Those states recognizing the right of privacy by statute do so in the limited form of prohibiting the use of plaintiff's name or likeness for advertising purposes. See UTAH CODE ANN. \$\$76-4-8, 76-4-9 (1953); VA. CODE ANN. $\S 8-650$ (1950); N.Y. CrviL RIGHTS LAW \$\$ 50-52.

Alabama: Smith v. Doss, 251 Ala. 250, 37 So. 2d 118 (1958); Arizona: Reed v. Real Detective Publishing Co., 63 Ariz. 294, 162 P.2d 133 (1945); California: Melvin v. Reid, 112 Ca1. App. 285, 297 Pac. 91 (1931). In Sidis v. F-R Publishing Corp., 113 F.2d 806 (2d Cir. 1940), the court of appeals declared that its holding, recognizing the right of privacy although denying recovery, represented the law of California, Georgia, Kansas, Kentucky and Missouri. Connecticut: Korn v. Rennison, 21 Conn. Supp. 400, 156 A.2d 476 (1959); Delaware: Barbieri v. News-Journal Co., 00 Del. 00, 189 A.2d 773 (1963); District of Columbia: Bernstein v. National Broadcasting Co., 129 F. Supp. 817 (D.D.C. 1955), aff'd on trial court's opinion, 232 F.2d 369 (D.C. Cir, 1956); Florida: Jacova v. Southern Radio \& Television Co., 83 So. 2 d 34 (Fla. 1955); Illinois: Annerino v. Dell Publishing Co., 17 Ill. App. 2d 205, 149 N.E.2d 761 (1958); Indiana: Estill v. Hearst Publishing Co., 186 F.2d 1017 (7th Cir. 1951); Iowa: Bremmer v. Journal-Tribune Publishing Co., 247 Iowa 817, 76 N.W.2d 762 (1956); Louisiana: Itzkovitch v. Whitaker, 115 La. 479, 39 So. 499 (1905); Maryland: Graham v. Baltimore Post Co., decided by Baltimore Superior Court in 1932; reported in full in 22 KY. L.J. 108 (1933). Michigan: Pallas v. Crowley, Milner \& Co., 322 Mich. 411, 33 N.W.2d 911 (1948); Montana: Welsh v. Roehm, 125 Mont. 517, 241 P.2d 816 (1952); New Jersey: Edison v. Edison Polyform \& Mfg. Co., 73 N.J. Eq. 136, 67 At1. 392 (1907); New Mexico: Hubbard v. Journal Publishing Co., 69 N.M. 473, 368 P.2d 147 (1962); North Carolina: Flake v. Greensboro News Co., 212 N.C. 780,195 S.E. 55 (1938); Ohio: Housh v. Peth, 165 Ohio St. 35, 133 N.E.2d 340 (1956); Oklahoma: Hazlitt v. Fawcett Publications, 116 F. Supp. 538 (D. Conn. 1953); Oregon: Hinnish v. Meier \& Frank Co., 166 Ore. 482, 113 P.2d 438 (1941); Pennsylvania: Schnabel v. Meredith, 378 Pa. 609, 107 A.2d 860 (1954); South Carolina: Holloman v. Life Ins. Co., 192 S.C. 454, 7 S.E.2d 169 (1939); Tennessee: Langford v. Vanderbilt University, 199 Tenn. 389, 287 S.W.2d 32 (1956); West Virginia: Roach v. Harper, 143 W. Va. 869, 105 S.E.2d 564 (1958).

3 Nebraska: Brunson v. Ranks Army Store, 161 Neb. 519, 73 N.W.2d 803 (1955); Rhode Island: Henry v. Cherry \& Webb, 30 R.I. 13, 73 Atl. 97 (1909); Texas: Milner v. Red River Valley Publishing Co., 249 S.W.2d 227 (Tex. Civ. App. 1952); Wisconsin: Yoeckel v. Samonig, 272 Wis. 430, 75 N.W.2d 925 (1956).

4 Alaska: Smith v. Suratt, 7 Alaska 416 (1926); Arkansas: Mabry v. Kettering, 89 Ark. 551, 117 S.W. 746 (1909); Colorado: McCreery v. Miller's Groceteria Co., 99 Colo. 499, 64 
found in the remaining eight jurisdictions. 5

The right of privacy is, in most of its forms, founded upon the recognition of the individual's interest in avoiding unwanted widespread publicity. ${ }^{6}$ There are, however, two distinct branches of this right: One appears to be concerned with emotional injury, or at least with some technical injury thought to arise, by analogy to trespass actions, from use of plaintiff's name or likeness; the other is concerned with the commercial exploitation of the plaintiff's name or likeness without compensation to him. The latter aspect of the right of privacy might conveniently be thought of as a "right to publicity."7 In either of its forms, there may be a collision with freedom of expression. Where "newsworthy" information is involved, the conflict has been resolved in favor of free expression by maintaining a privilege to publish $^{8}$ substantially accurate

P.2d 803 (1936); Massachusetts: Kelley v. Post Publishing Co., 327 Mass. 275, 98 N.E.2d 286 (1951); Minnesota: Berg v. Minneapolis Star \& Tribune Co., 79 F. Supp. 957 (D. Minn. 1948); Mississippi: Martin v. Dorton, 210 Miss. 668, 50 So. 2 d 391 (1951); Nevada: Norman v. City of Las Vegas, 64 Nev. 38, 177 P.2d 442 (1947); Washington: Lewis v. Physicians \& Dentists Credit Bureau, 27 Wash. 2d 267, 177 P.2d 896 (1947).

5 Hawaii; Idaho; Maine; New Hampshire; North Dakota; South Dakota; Vermont; Wyoming.

6 Prosser, ToRTs 641 (2d ed. 1955): "Except in the cases of physical intrusion, it has been held that the tort must be founded upon publicity, in the sense of communication to the public in general or to a large number of persons, as distinguished from one individual or a few." See also GREGORY \& KALVEN, CASES ON TORTS 884 (1959): "As a separate tort heading ... the right of privacy is a relatively narrow and technical term of art and concerns primarily-although not exclusively-freedom from publicity by mass communication." Prosser has catalogued the forms of the right of privacy as follows: "The right has been held to cover intrusions upon the plaintiff's solitude; publicity given to his name or likeness, or to private information about him; placing him in a false light in the public eye; and the commercial appropriation of elements of his personality. The right is subject to a privilege to publish matters of news value, or of public interest of a legitimate kind." PROSSER, op. cit. supra at 635 . For a detailed discussion of these forms, see generally Prosser, Privacy, 48 CALIF. L. REV. 383 (1960).

7 See GREGORY \& KALVEN, op. cit. supra note 6, at 1255: "It is now widely recognized that the right of privacy covers two quite different situations: (1) the emotional injury tort where plaintiff complains of interference with his tranquillity because of the unwanted publicity given him by defendant; (2) the business tort where plaintiff complains of the "free ride" the defendant gets by exploiting the good will of the plaintiff without payment to plaintiff." With regard to the questions of emotional injury and the analogy to trespass: In Bernstein $v$. National Broadcasting Co., 129 F. Supp. 817, 835 n.45 (D.D.C. 1955), plaintiff claimed that his privacy action was based on his suffering emotional injury: "It is to be emphasized that the reaction of third persons is not pertinent. It is the outrage, mental suffering, shame, or humiliation of a normal person in plaintiff's position which governs." But see GREGORY \& KALVEN, op. cit. supra note 6, at 891: "There appears to be considerable uncertainty as to whether the tort is to be limited to some standard of sensitivity to publicity set by the reasonable man or 'the man of customary phlegm,' or whether, on analogy to trespass actions, any unconsented use of plaintiff's name, likeness, etc., would be actionable and warrant at least nominal damages. One of the most interesting cases in this connection is Cason v. Baskin, 20 So. 2d 324 (Fla. 1945)."

8 Terms such as "publish" and "publication" will be used here in a broad sense as relating to products of any medium-newspapers, magazines, books, motion pictures, television, speeches in person before large audiences. 
reports" of the relevant events. ${ }^{10}$ Recognition of a privilege to publish "matter which is of public or general interest" was suggested by Warren and Brandeis, who drew an analogy to the qualified privilege of comment and criticism on matters of public interest as a defense in defamation actions.11 This privilege, however, is less expansive than the broad privilege to publish anything qualifying as "newsworthy" which limits the right of privacy.12 The scope of this "newsworthiness privilege" is potentially a critical issue in all privacy cases, but an examination of those cases involving reports of long past newsworthy events may be of particular assistance in analyzing the privilege since the court must consider whether newsworthiness has persisted.

The question presented by cases involving reports of long past events in which plaintiff was an actor is whether the newsworthiness privilege persists indefinitely or is subject to extinction by the passage of time. More simply: Can a newsworthy event ever cease to be newsworthy? Prevailing authority appears to hold that passage of time alone does not extinguish the newsworthiness privilege. 13 Sidis $v$. F-R Publishing Co., 14 which is probably the leading privacy case, represents the majority view on this point. The court held that the publication of stories in the New Yorker describing in great detail the present life of a former child prodigy who, a generation before, had abandoned his widely publicized academic pursuits and fallen into obscurity, was not an invasion of privacy.

9 Unless otherwise indicated, it will be understood that the reports identify the plaintiff; if there is no identification, a cause of action in privacy cannot arise. See Bernstein v. National Broadcasting Co., 129 F. Supp. 817 (D.D.C. 1955).

$10 \mathrm{It}$ does not appear, however, that where an individual's activities are held to be not newsworthy, reporting them must constitute an invasion of privacy; in order to establish a prima facie case, the plaintiff apparently must prove that there has been a minimum threshold invasion of privacy as a result of an unconsented report. "The puzzle with respect to the first two categories of plaintiffs [those in no sense newsworthy, and those involuntarily newsworthy] is, in effect: what threshold interference with privacy is needed to constitute the tort? Is, for example, any use of the plaintiff's name, likeness, or personal biography, which is not consented to, a tort unless privileged? Prosser states that the interference must be 'serious and outrageous or beyond the limit of common ideas of decent conduct.' Prosser, TORTS 635 (2d ed. 1955)." Gregory \& Kalven, op. cit. supra note 6, at 889.

11 Warren \& Brandeis, supra note 1, at 214. See 1 HARPER \& JAMES, ToRTs 457 (1956); RESTATEMENT, TORTS $\S 606$ (1938).

12 See, e.g., Louisville Times Co. v. Lyttle, 257 Ky. 132, 141-42, 77 S.W.2d 432, 436-37, (1934); Prosser, Torts 619 n.53 (2d ed. 1955).

13 Barbieri v. News-Journal Co., 000 Del. 000, 000, 189 A.2d 773, 775 (1963): "But we do not agree that the lapse of time, in itself, recreates, or reinstates, a plaintiff's prior right of privacy, because the right of the press to republish the unpleasant facts still exists if those facts are 'newsworthy,' i.e., if they still are of legitimate public concern."

See Carlisle v. Fawcett Publications, Inc., 201 Cal. App. 2d 733, 20 Cal. Rptr. 405 (1962); Smith v. National Broadcasting Co., 138 Cal. App. 2d 807, 292 P.2d 600 (1956); Molony v. Boy Comics Publishers, 277 App. Div. 166, 98 N.Y.S.2d 119 (1950); Schnabel v. Meredith, 378 Pa. 609, 107 A.2d 860 (1954).

14113 F.2d 806 (2d Cir. 1940). 
The Sidis case exposes a crucial dilemma pervading the privacy field: Is the term "newsworthy" a descriptive predicate, intended to refer to the fact that there is widespread public interest? Or is it a value predicate, intended to indicate that the publication in question is a meritorious contribution and that the public's interest is praiseworthy? The Sidis opinion, in stating that the plaintiff's "subsequent history, containing as it did the answer to the question whether or not he had fulfilled his early promise, was still a matter of public concern,"15 suggests that the New Yorker stories contributed something of value to the public. But in the next sentence, the court observes that the "article in the New Yorker sketched the life of an unusual personality, and it possessed considerable popular news interest," thus suggesting that the fact of widespread interest itself justified the publications. ${ }^{16}$ Was the court's view on the merits of the publication and of the widespread interest controlling, or was it only deferring to popular taste? The importance of the answer is clear: If "newsworthy" is simply a descriptive term, then the newsworthiness privilege has engulfed the tort of invasion of privacy. The publisher has almost certainly published any given report because he judged it to be of interest to his audience, and believed that it would encourage them to purchase his publications in anticipation of more of the same. The mere existence of his self-interest would seem to be compelling evidence of the newsworthiness of anything he published. A plaintiff in a privacy action would thus have lost almost before he started. The difficulties of proving that a published item, distributed widely, was not really very interesting to the greater part of the audience seem considerable. And even if proved, it is hard to see why publication of an uninteresting item-probably ignored by most of the audience-would be a greater injury to the plaintiff or indicate a higher degree of fault in the defendant than publication of an interesting item. But if "newsworthy" has normative meaning, the courts are evaluating the public's interest.17 If adequate

15 Id. at 809 .

${ }_{16} C f$. Hazlitt v. Fawcett Publications, 116 F. Supp. 538, 544 (D. Conn. 1953) (referring to an automobile stunt driver who had often performed in public): "Nor, I think, could he object to publications of such accounts and comment at subsequent stages in his career. That is so, I think, because the interest of the public (or a substantial segment thereof) in sports events is as legitimate as it is real. So highly personal is the interest of the public in 'public figures' that I doubt that it is actionable to publish fair reports of incidents in a private life not directly related to the qualities or achievements upon which the status of a public figure depends." Other cases which appear to regard "newsworthy" as simply a descriptive term are Jenkins v. Dell Publishing Co., 251 F.2d 447, 452 (3d Cir. 1958); Goelet v. Confidential, Inc., 5 App. Div. 2d 226, 171 N.Y.S.2d 223 (1958).

17 The relationship between the issue of whether an item is newsworthy and the issue of whether it is indecent or offensive to ordinary sensibilities requires clarification. It seems clear that newsworthiness and decency or inoffensiveness are distinguishable concepts. Although the newsworthiness of an event may imply that a dry, objective report of it would be inoffensive, the reverse implication is not true; and the nonnewsworthiness of an event does not imply the offensiveness of its being publicized in a detached manner. The distinction between the character of an event and the circumstances of its reporting is useful in separating the concepts in question. The offensiveness of a report may be due to the manner 
standards for this judgment cannot be found, then the limitations on free expression created by the tort of invasion of privacy may be in danger of attack on constitutional grounds.

A further complication in analyzing the structure of the tort of invasion of privacy is the conceptual confusion attending the courts' treatment of the motives and purposes of the publishers in determining whether a publication is actionable. The question arises whether proof of certain states of mind serves as a direct limit on the newsworthiness privilege-thus making it a "qualified" privilege-or is simply regarded as a clue to the likely effect of the published item, such effect being determinative of whether it is privileged. An examination of cases involving publication long after the currency of the events reported may provide some groundwork for the analysis of both the dilemma of normative ambiguity and the role of motive and purpose.

As stated above, the general rule is that lapse of time is not a sufficient condition for the extinction of the newsworthiness privilege. The recent case of Wagner v. Fawcett Publications, however, suggests a radical departure from this rule. The case concerned the publication of stories of the rape-murder of plaintiff's daughter two months after the crime had occurred. In its original opinion, the Seventh Circuit reversed the district court and held the publication actionable. 18 The decision may be construed as holding either that the newsworthiness privilege had automatically expired, or that it had been limited by the existence of a wrongful purpose on the part of the publishers to entertain their audience. Since the finding of a wrongful purpose was apparently determined by the fact that the events reported were not current, time passage was crucial in either view:

Addressing ourselves to Fawcett's attack upon the complaint on the ground that matters set forth in its publication were newsworthy, of great public interest, and designed to inform and educate its readers, we are of the opinion that the trier of facts could find the articles in question, published months after the death of Mary Lou Wagner, had ceased to be news and

of the recounting of the events concerned, to the context in which it was published, $c f$. Jenkins v. Dell Publishing Co., 251 F.2d 447, 452 (3d Cir. 1958), or to the character of the events themselves. Otherwise newsworthy events may be referred to in an offensively written article. The notions of indecency and offensiveness, then, should be thought of as being used to limit the newsworthiness privilege, but not as being coextensive with the concept of nonnewsworthiness.

The dissenting opinion in Gill v. Hearst Publishing Co., 40 Cal. 2d 224, 232, 253 P.2d 441,445 (1953), clearly distinguished the two issues: "[T]here are two main questions involved in right of privacy cases: (1) Is the publication of a character which would offend the feelings and sensibilities of the ordinary person; and (2) if it does so offend, is there such a public interest in the subject matter of the publication in reference to its news or educational significance that it may be published with impunity." The view expressed here is evidently that newsworthiness is a complete defense in privacy actions, not limited by the "ordinary sensibilities" test.

18 No. 13541 (7th Cir. June 18, 1962), rev'd on rehearing, 307 F.2d 409 (1962), cert. denied, 372 U.S. 909 (1963). The first opinion was withdrawn and is not to be published. 
for that reason these articles were not published in news media, but in magazines sold for the entertainment of their readers. By our holding we in no way suppress the legitimate publication of news; rather we condemn the pursuit for commercial purposes of those who may have been connected with matters which were, at the time of the occurrence, newsworthy. When the news media have served their proper function in reporting current events, private individuals involved therein sink back into the solitude which is the right of every person. That solitude involves a privacy which no publication has a right to thereafter invade solely for the purpose of selling to its readers lurid accounts of tragedy. 19

Upon rehearing, however, the court reversed itself solely on the ground that the events in question actually were still current; it reached this decision on the basis of evidence showing that legal proceedings were taking place against the accused at the time of publication. The rule stated in the original opinion, regarding the decisive effect of time lapse, seems to have remained intact, limited only by the condition that the sequence of newsworthy events stemming directly from the original events shall have come to an end.

Little light is shed on the meaning of "newsworthiness" in this opinion. Admittedly, the events were newsworthy at the time they occurred. If the decision is construed as holding that the newsworthiness privilege had automatically expired, the view implicit in this holding is that the ordinary changes over time-public and private forgetfulness, the return to relative peacedestroyed the newsworthiness. But it is unclear why these gradual and subtle changes should transform a newsworthy event into a nonnewsworthy one.

If the decision is construed as holding that passage of time is conclusive evidence of a wrongful purpose, then the further questions arise: How does the lapse of time tend to prove a wrongful purpose? And what do the motives of the publisher, considered alone, have to do with whether there has been an invasion of privacy? As to the first question: The role of passage of time as evidence of a wrongful purpose-e.g., to entertain or amuse-can only be based on a belief that the publisher probably could have had no other purpose, such as to "inform" or "educate," because no worthwhile information could be conveyed at such a late date. But this is simply equivalent to saying that the events in question are not newsworthy, in the normative sense. The showing of a wrongful purpose and commercial exploitation would thus seem to be superfluous 20 and there would be no need to prove the propositions for which time passage is introduced as evidence.

19 The quotation is from the withdrawn opinion, ibid. A rule similar to that stated in the last sentence is found in RESTATEMENT, ToRTs $\$ 867$, comment $c$ (1939), but this rule does not assert that when the plaintiff has sunk into solitude, his past actions have similarly become protectively enveloped in solitude. Simply to say that a person has slipped back into solitude implies that reports of his current, continuing activities are not privileged, but not that his past newsworthy activities cannot be recounted by reason of his present status.

20 This may not be the case where a statute makes the question of commercialization crucial. See, e.g., the N.Y. CivI RIGHTS LAW \$§ 50-52. 
As to the role of the publisher's motives: It is not clear whether a formal limitation on the newsworthiness privilege-similar to the limitations on privileged publication in defamation actions-was contemplated, or whether the motives and purposes of the publisher were used as indicators of the likely effect of the publication. The principal conclusion to be drawn from the opinion seems to be that events are newsworthy only if they are current.21 The mere fact that legal proceedings were still in progress against the accused seems a tenuous ground for denying recovery, but the reliance on currency alone as an indicator of newsworthiness drew the court to this view.

Analysis of the role of time passage in the Sidis case seems more enlightening on the question of the scope of the newsworthiness privilege. If we are concerned with passage of time-and therefore change-the significant question to ask in analyzing what effect time passage should have on adjudicating privacy cases seems to be this: Have any significant changes, inevitable or contingent, taken place since the occurrence of the reported events, which changes should be critical in determining the legal relations of the parties? Ignoring for present purposes the court's reference to "popular interest," time passage appears to have been significantly involved in the Sidis case in that it brought with it the opportunity to discover the results of publicizing and exploiting young genius, the reporting of such results being of some social benefit. The inevitable maturity of Sidis was the critical change creating the possibility of advancing the important policy of evaluating the treatment of the gifted. More generally, the court, in considering the utility of the publication at the time of publication, necessarily took into account conditions which might have arisen or persisted since the occurrence of the events. Passage of time was thus crucial because the question whether there were any significant changes in conditions was relevant in determining the usefulness of the publication, at the time of publication. The role of passage of time appears to have been that of a necessary precondition for the realization of an opportunity to further some social policy. It cannot be determined how youthful genius turns out until the genius is no longer youthful; it may confidently be asserted that passage of time is essential to the change from youth to maturity.

It seems clear that the content of the implicitly used concept of newsworthiness was normative. The court appears to have balanced the interests of the public in learning of Sidis' fate against Sidis' interest in maintaining his privacy, and concluded that the information complained of was sufficiently valuable to overcome his interest. Unfortunately for the plaintiff, it appears that no changes over time could have destroyed his newsworthiness: If his gifts had waned, this phenomenal change would surely have been a subject of

21 This would seem an unexceptionable thing to say of "news"; but "newsworthy" and "news" hardly seem to be synonymous terms. Nevertheless, if a court holds that the newsworthiness privilege is extinguished automatically by passage of time, it may be committed to asserting their synonymy. 
legitimate public interest. And the mere endurance of his gifts might make him continuingly newsworthy.

The decision in Melvin $v$. Reid 22 upheld recovery by plaintiff, a reformed prostitute, who complained of the distribution of a movie depicting her in her former occupation and dramatizing her acquittal in a murder trial. But the case is not in conflict with the general rule that time lapse is not sufficient to destroy the newsworthiness privilege, in view of the policy considerations invoked by the court:

One of the major objectives of society as it is now constituted, and of the administration of our penal system, is the rehabilitation of the fallen and the reformation of the criminal. Under these theories of sociology it is our object to lift up and sustain the unfortunate rather than tear him down. Where a person has by his own efforts rehabilitated himself, we, as rightthinking members of society, should permit him to continue in the path of rectitude rather than throw him back into a life of shame or crime. Even the thief on the cross was permitted to repent during the hours of his final agony. 23

Again, examination of the role of time lapse clarifies the court's effective views on newsworthiness. The critical change in conditions was the advanced state of rehabilitation of the plaintiff. Its role in this case thus appears to be similar to its role in Sidis: In Melvin, lapse of time brought with it changes of such nature that important policies were impeded by publication; in Sidis, it brought changes of such nature that important policies were advanced by publication. In each case, the court examined the conditions existing at the time of publication. Time passage was thus relevant in both cases without being determinative. "This change having occurred in her life, she should have been permitted to continue its course without having her reputation and social standing destroyed by the publication of the story of her former depravity with no other excuse than the expectation of private gain by the publishers." 24

22112 Cal. App. 285, 297 Pac. 91 (1931).

23 Id. at 292, 297 Pac. at 93.

24 Ibid. (Emphasis added.) See also Bernstein v. National Broadcasting Co., 129 F. Supp. 817 (D.D.C. 1955), aff'd on trial court's opinion, 232 F.2d 369 (D.C. Cir. 1956). On the basis of policy considerations applicable at the time of televising, the court determined whether a dramatization of plaintiff's rescue from a death sentence through the efforts of a woman reporter who had discovered new evidence yielded any advantageous results. Thus, although most of the policy considerations involved would have applied at the time the newsworthy events had occurred, the court, by considering the possible effects of the dramatization, would necessarily have taken into account any new policy considerations arising since the occurrence of the events. Denying recovery, the court stated: "The program of January 18, 1952 , although sponsored commercially, was one of general interest. It did not single out plaintiff to expose him to public scorn, but was one of a series of television plays devoted to retelling in fictionalized form the stories of newspaper reporters who had done excellent work in promoting justice. As the New Yorker sketch in the Sidis case . . . might be of current public value in pointing out to parents the unhappy results of forcing a child prodigy into public notoriety, 'The Big Story' program was of current public value in demonstrating how an alert reporter, who has an interest in seeing right prevail, may help an innocent man 
As in Sidis, the implicit use of the newsworthiness concept was normative: The court assessed the value of the publication involved.

In the recent case of Barbieri v. News-Journal,25 the court explicitly rejected Melvin, holding that a newspaper article concerning a proposal to make whipping mandatory for certain crimes did not invade the privacy of a man identified as having been a victim of this punishment nine years before, but who had since lived a blameless life. The Delaware court apparently felt that the decision in Melvin wrongly rested upon notions of "decency" or "good taste," with which courts should not be concerned:

[W]e must express a serious doubt whether the basis of the decision [Melvin] . . . is a sound one on which to sustain an action for invasion of privacy. Such a rule would in reality subject the public press to a standard of good taste-a standard too elusive to serve as a workable rule of law. ... [W] cannot agree to impose upon the public press a legal standard founded on such considerations. There must be something more than the mere publication of facts of record relating to a matter of public interest. ... There is nothing in the article ... which violates the ordinary decencies, ... [nor was there] an attempt to exploit the plaintiff's life for commercial reasons. ${ }^{26}$

But the court in Melvin does not seem to have been concerned primarily with policies of maintaining standards of decency and good taste; rather, it was concerned with the value or lack of value of the motion picture in furthering or subverting other social policies. In construing Melvin as it did, the Barbieri court may have regarded the concept of newsworthiness as primarily a matter of decency and good taste. But while these concepts may provide limits to the defense of newsworthiness, or possibly even form part of the concept of newsworthiness, they do not seem to form the whole of it. Considerations of social utility can be made independently of considerations of taste and decency, and a publication can be nonnewsworthy or positively harmful for reasons other than being indecent or offensive. 27

There are several cases in which the combination of time lapse with one or more other factors has been sufficient to extinguish or limit the newsworthiness privilege, although none of these factors was independently sufficient to do so. An examination of these additional factors-a "wrongful purpose" on

escape the consequences of a wrongful conviction, and perhaps might inspire some other reporter to greater efforts or some young person to embrace a newspaper career." 129 F. Supp. at 835 .

25000 Del. 000, 189 A.2d 773 (1963).

26000 Del. at 000,189 A.2d at 776.

27 Cf. Mau v. Rio Grande Oil Co., 28 F. Supp. 845 (N.D. Cal. 1939). The court held that a radio dramatization of a holdup in which plaintiff was the victim was an invasion of his privacy. It would be difficult to conclude that there was anything "indecent" or "offensive" about the dramatization of a holdup. 
the part of the publishers, and the presence of fictionalized material-may be helpful in determining the limits of the concept of newsworthiness.

Melvin v. Reid expressed the view that the distributors of the motion picture had no other purpose than to reap financial gain. Apparently the court found objectionable the absence of a purpose to perform a service in disseminating useful information, and thought any other purpose would be wrongful. 28 The presence of a wrongful motive might thus serve as a direct limit on the newsworthiness privilege. A publication in a different medium, e.g., a journal of criminology, containing the same factual material and identifying the plaintiff, might have withstood assault. 29 But employing such a limitation does not determine whether a court is using "newsworthy" normatively or descriptively, for both publications which are valuable and publications which are merely of wide interest may be published for objectionable reasons.

It is difficult to see how conveying the same information for different purposes has any direct bearing on whether plaintiff has been injured. The motives of the publisher are significant to the extent that they affect the treatment of the news events. The characteristics of the report as well as of the events reported should be critical in determination the rights of the parties. Thus, in Goelet v. Confidential, Inc., 30 the court, granting defendant's motion to dis-

28 Whether the courts are justified in making a distinction between publications whose purpose, or effect, is predominantly to entertain rather than to edify is questionable in light of Winters v. New York, 333 U.S. 507 (1948), which states: "We do not accede to appellee's suggestion that the constitutional protection of free speech extends only to the exposition of ideas. The line between the informing and the entertaining is too elusive for the protection of that right. Everyone is familiar with instances of propaganda through fiction. What is one man's amusement, teaches another's doctrine. Though we can see nothing of any possible value in these magazines, they are as much entitled to the protection of free speech as the best of literature." Id. at 510. Some privacy cases explicitly reject the distinction. See, e.g., Jenkins v. Dell Publishing Co., 251 F.2d 447 (3d Cir. 1958). In considering the question of the nature of the publication in which a report appears, apart from a consideration of the nature of the report itself, the court said: "In this case we think that even the appellants would not deny that a January 1954 publication in the Pittsburgh daily papers of the identical story and supporting picture which appeared at that time in Front Page Detective would be a privileged news item. For the purposes of the law of privacy we cannot see how the character of the item can be affected by the journal in which it appears." Id. at 452 .

${ }^{29}$ Cf. Hazlitt v. Fawcett Publications, Inc., 116 F. Supp. 538, 545 (D. Conn. 1953): "Indeed, even if the plaintiff here were not deemed a public figure by occupation, his involuntary catapult to temporary notoriety because of involvement in a homicide left him without the right to object to fair news accounts of the homicide and of his arrest and trial and without right to object to mention of his occupation in that connection. Perhaps, also, later accounts containing information relating to criminal history or administration of interest either to a lay or professional public would not have been actionable."

305 App. Div. 2d 226, 171 N.Y.S.2d 223 (1958). See also Leverton v. Curtis Publishing Co., 192 F.2d 974, 978 (3d Cir. 1951), where the court, in referring to Mau v. Rio Grande Oil Co., 28 F. Supp. 845 (N.D. Cal. 1939), discussed note 27 supra, stated: "The news account of the holdup was, of course, comparable to a news account of a traffic accident. But when this account came to be the basis for public entertainment, the court considered the bounds of privilege exceeded. We think the same is true here." And see Feinberg, Recent Developments in the Law of Privacy, 48 CoLUM. L. Rev. 713, 721 (1948): "As such, the "public 
miss a complaint alleging that the report complained of was published for the purpose of "public amusement" rather than the dissemination of information, stated:

A qualification to the right to publish items regarding public figures was stated in the Gautier case [Gautier v. Pro-Football, 304 N.Y. 354, 359, 107 N.E.2d 485, 487 (1952)] . . . "While one who is a public figure or is presently newsworthy may be the proper subject of news or informative presentation, the privilege does not extend to commercialization of his personality through a form of treatment distinct from the dissemination of news or information." 31

This notion of "commercialization" has been important in a number of privacy cases, and, as suggested by Goelet, it may be an ultimate issue for the defense which is proved by evidence of certain characteristics of the report. One such characteristic may be the presence of fictionalized material, which can serve not only as an indicator of commercialization, if that is the concept employed in limiting the newsworthiness privilege, but as an independent direct limit on this privilege, without the intervention of the issue of commercialization. ${ }^{32}$ Hazlitt v. Fawcett Publications ${ }^{33}$ seems to give both effects to fictionalization and possibly to time lapse. ${ }^{34}$ The court held actionable on a count in privacy a magazine article which stated that plaintiff, an auto stunt driver, had killed a man while participating in a traveling circus and attempted to conceal responsibility for it, but was detected, tried and convicted. The plaintiff alleged that no such attempted concealment had occurred and that he had been found not guilty. The court said:

[T] o the extent that the defendant indulged in fictionalization, the inference gathers strength that the dominant characteristic of the story was not genuine information but fictional readability conducive to increased circulation for the magazine... Thus this count [in privacy] may be deemed to state an actionable claim on the theory that the published story was in essence not a vehicle of information but rather a device to facilitate com-

interest in information' might protect the disclosure, but not the use to which the details of Mau's unfortunate experience were put. In other words, this use was not primarily informational, hurt the plaintiff, and might, therefore, be properly held to be tortious."

315 App. Div. 2d 226, 228-29, 171 N.Y.S.2d 223, 225-26 (1958).

32 Cf. Molony v. Boy Comics Publishers, 277 App. Div. 166, 172, 98 N.Y.S.2d 119, 124 (1950). "Whether his reputation has been enhanced or degraded does not relate to whether he has been fictionalized, which determines whether his statutory right of privacy has been invaded." But the court may have simply regarded fictionalization as proving, as a matter of law, that there had been a commercial exploitation.

33116 F. Supp. 538 (D. Conn. 1953).

34 It is doubtful whether time lapse was thought to have any independent direct effect, as was the case in Wagner v. Fawcett Publications, No. 13541 (7th Cir. June 18, 1962), rev'd on rehearing, 307 F.2d 409 (1962), cert. denied, 372 U.S. 909 (1963). Its effect probably derived from its conjunction with fictionalization. See Note, 42 IowA L. REV. 455, 457 (1957). 
mercial exploitation. ... And this conclusion is further strengthened by the two-year time lag between the criminal trial and the publication. 35

Elsewhere the court quoted approvingly from the plaintiff's brief:

[T] hese statements [the true ones] alone are sufficient to injure the plaintiff, and were not a publication made in the public interest because they were stale and coupled with fictionalized material. ${ }^{36}$

It thus appears that newsworthiness is not a complete defense in privacy cases, but may be limited by the presence of fictionalized material or a wrongful purpose. The existence of these limits seems entirely neutral as regards the issue of whether "newsworthy" is a descriptive or normative adjective. Despite widespread interest or positive value to society in learning of the information disseminated, the defendant's interest in free expression may be defeated by an embroidery of the facts or a purpose to exploit the plaintiff commercially. 37

\section{ConClusion}

A number of privacy decisions involving the publication of reports of noncurrent events have been examined to determine the nature of the newsworthiness privilege. In general these cases hold that although time lapse is

${ }^{35}$ Hazlitt v. Fawcett Publications, 116 F. Supp. 538, 545 (D. Conn. 1953).

36 Id. at 544.

37 The involuntariness of plaintiff's behavior or role may also influence a court in finding an invasion of privacy. The decision in Mau v. Rio Grande Oil Co., 28 F. Supp. 845 (N.D. Cal. 1939), discussed note 27 supra, might be read as one in which the involuntariness of plaintiff's behavior, conjoined with passage of time and the presence of a wrongful purpose, served to limit the newsworthiness privilege. The case is, however, quite ambiguous. It cited Melvin v. Reid, 112 Cal. App. 285, 297 Pac. 91 (1931), as "controlling" without explanation, and sheds little light on the nature of the newsworthiness privilege. Compare Goelet v. Confidential, Inc., 5 App. Div. 2d 226, 171 N.Y.S.2d 223 (1958), with Sutton v. Hearst Corp., 277 App. Div. 155, 98 N.Y.S.2d 233 (1950). It should be noted that the conjunction of any of the factors mentioned-wrongful purpose, fictionalization, involuntariness of conduct or role-may jointly be more effective in limiting the privilege than if only one element is present.

The importance of the distinction between voluntary and involuntary conduct or role is further suggested by cases holding that persons actively seeking publicity or engaging in conduct likely to lead to publicity have irrevocably "waived" their right of privacy. In Cohen v. Marx, 94 Cal. App. 2d 704, 211 P.2d 320 (1950), Groucho Marx, during a radio program, made an uncomplimentary jocose remark about a fighter named "Canvasback Cohen." The court held that plaintiff Cohen, a former boxer, had "relinquished his right to privacy in matters pertaining to his professional activity." Id. at 705, 211 P.2d at 321. Accord, Gill v. Hearst Publishing Co., 40 Cal. 2d 224, 253 P.2d 441 (1953). The concept of newsworthiness may be wholly irrelevant in these cases, proof of a "waiver" being used either to show that there is not even a prima facie invasion of privacy, or as an independent defense. Given the automatic effect of the waiver, the concept of newsworthiness has no role in the court's reasoning. Yet this waiver theory leaves as little of the tort of invasion of privacy as does a descriptive sense of "newsworthiness" in cases involving voluntary conduct likely to result in publicity. But cf. Ettore v. Philco Television Broadcasting Corp., 229 F.2d 481 (3d Cir. 1956), where a former boxer recovered damages after the televising of his old boxing films. 
not sufficient to extinguish the privilege, it is a relevant factor in a determination of its existence. In those which consider the question whether newsworthiness has persisted, the opinions are sometimes helpful in revealing that the court has adverted to specified changes generating new policy considerations not applicable when the events occurred. The publisher's state of mind or the presence of fictionalized material are factors that may, in combination with time lapse, destroy the privilege.

These decisions also reveal the critical ambiguity of the term "newsworthy": If the scope of the newsworthiness privilege is fixed by reference to the range of popular interest, then little is left of the tort of invasion of privacy; it would be difficult to suppose that publishers were in the habit of reporting occurrences of little interest. But it seems bootless to structure a tortprivilege relation so that the privilege effectively annihilates the tort. Further, defining the privilege in such a manner ignores the possibility that types of events which naturally arouse great interest may, in the judgment of the same community which is interested, be interesting for objectionable reasons, even when the reports of the events fall short of being indecent. Thus, the legislative judgment of the state of Wisconsin in prohibiting the use of the names of rape victims in published reports ${ }^{38}$ reflects both the judgment that such identification is harmful, and that positive law was required as a self-restraint to prevent what would otherwise be published because of a community interest that the community itself thinks objectionable.

But if "newsworthy" is a moral predicate, then the courts will in each case have to determine what social policies are, through their being advanced or subverted by publication, relevant in determining whether an event is newsworthy. Particularly in need of clarification is the role of the publisher's state of mind as a limit to the defense of newsworthiness. If that which is immune when published for one purpose is held actionable when published for another, the courts and legislatures may run afoul of constitutional requirements of due process or equal protection. ${ }^{39}$ Since different publications and media may have different purposes, to make certain purposes elements of the tort of invasion of privacy may bring a publication or medium under a wide interdict not to publish what other publications and media may publish with impunity.

38 Wis. Stat. AnN. ch. $942 \S 2$ (1955). State v. Evjue, 253 Wis. 146, 33 N.W.2d 305 (1948), held that the purpose of the statute was to save from embarrassment and offensive publicity women who had been victims of the sexual assaults delineated in the statute. It went on to say that "the publication of the identity of the female ministers to a morbid desire to connect the details of one of the most detestable crimes known to the law with the identity of the victim." Id. at 161, 33 N.W.2d at 312 .

39 Winters v. New York, 333 U.S. 507 (1948), although concerned with the question of unconstitutional vagueness, observes that a consequence of such vagueness may be to discriminate between different types of publications in a manner evidently thought to be constitutionally forbidden. 